\title{
6. 老年者癌の特徵
}

\author{
金子 仁
}

\section{はじめに}

老年者癌がクローズアップされたのは最近, 日本人の 平均寿命が延長されたことが最も大きい原因である。今 まで, 伝染病や結核で死亡した人も抗生物質その他で助 かる様になったからである。

私は老年者癌の病理学的特徵を検討すべく自分で剖検 し，自分で鏡検した例のみを主な対象として考察した。 病理学的診断や分類は同一の眼で見ないと成績に統一性 を欠くららみがあるからである。

\section{肉腫について}

癌がテーマであるが，同じ悪性腫瘍で老年者の肉腫は どの様な特徴があるのだろらか。この様な発想から, 昭 和35年より 8 年間, 国立東一病院で自分が診断した肉腫 を全部再検討した. 60 歳以上22例, 59歳以下44例である. 60 歳以上の肉腫の内, 最も多いのは細網肉腫で13例（59 $\%$, 次いで線維肉腫 4 例, 平滑筋肉腫 3 例, 骨肉腫・ 横紋筋肉腫各々 1 例である.

興味あるのは，67歳女性の骨肉腫で，組織学的にオス テオイド形成が極めて著明な点である。横紋筋肉腫は73 歳男性で17年前に左大腿部に発生し, 摘出再発をくり返 した. 組織学的には比較的分化した細胞より出来てい る.

老年者肉腫の特徵は, 細網肉腫が最も多く見られる点 である又他の肉腫には分化した形が多く認められたが， 症例数が少ないので直ちに特徵とするわけにゆかない．

\section{癌の統計学的事項}

老年者はどこの癌が一番多いのであろらか。こんな考 えから私が診断にタッチしている下館市民病院（昭和 47〜昭和52年), メディカルサイエンス（昭和47～昭和 52 年), 賛育会病院 (昭和 50 昭和 52 年), 東洋微生物研

M. Kaneko：日本医科大学老人病研究所病理
（昭和46～昭和52年）の全生検中，70歳以上の悪性腫瘍 を上位から拾うと, 下館病院は, 胃癌 - 子宮癌・大腸癌 （直腸癌を含む）・食道癌・前立腺癌, メディカルサイ エンスは, 胃癌・子宮癌・大晹癌・乳癌・前立腺癌, 賛 育会病院は, 胃癌 -子宮癌 - 大晹癌・皮虐癌 - 乳癌, 東 洋微告物研では, 胃癌・乳癌・皮㲊癌・大腸癌・ 子宮癌 の順である。

いずれの施設でも最も多いのは胃癌が共通して㧊り， 次いで子宮癌・乳癌・大腸癌が多い部類である。特に70 歳以上胃癌は全胃癌に対して, 下館病院で $24.8 \%$, メデ ィカルサイエンス $15.7 \%$, 賛育会病院 $13.8 \%$, 東洋微生 物研 $16.0 \%$ である。

これらはすべて生検材料であるが，剖検例ではこの様 なランク付けが出来るだろらか.

大津正一博士は, 東京都養育院病院 - 福祉法人浴風会 病院は共に60歳以上の 老人を収容する施設であるが， 前者の剖検して確めた悪性腫瘍66例中胃癌が最も多く19 例, 後者も60例中 27 例で同様に胃癌が最も多いと述べて いる. 又, 幸いに我国には日本病理学会で編集した日本 病理剖検輯報が，昭和33年度より現在まで刊行されてい る.これは我国の大学始め主要病院で行われた病理解 剖所見を集録したものである. 私は昭和 33 年・36年・40 年・45年・50年の統計を検索し第 1 表 (男性), 第 2 表 （女性）にまとめた。

我国に於ける70歳以上の癌は, 各年度を通じ男女共に 胃癌が最も多い。但し昭和40年女性で肺癌は胃癌より多 い. 次いで，男性では，肺・大腸・胆・肝，食道が多 く，女性では，肺・大腸・子宮・乳房が多い。

一方, 厚生省大臣官房統計調查部の発表した全死因統 計のうち, 覀性腫瘍に関するデータを日本医大衛生学教 室柚木斉教授の御厚意で見せて載き, 第 3 表 (男性), 第 4 表（女性）の如く昭和 33 年・ 36 年・ 40 年・ 45 年の分 を比較した．剖検輯報に比較すれば剖検しない例も入る ので死因の正確度は低いが，実数では圧倒的に多い，や はり70歳以上の癌では男女共に, 各年代を通じて胃癌が 
第 1 表 日本病理剖検輯報悪性新生物統計（今）

\begin{tabular}{|c|c|c|c|c|c|c|c|c|c|c|c|c|c|}
\hline & 胃 & 肺 & 食 道 & 腸 & 胆 - 肝蔵 & 脺 & 前立腺 & 細網肉腫 & その他 & 総 \\
\hline $\begin{array}{l}\text { 昭 } \\
\text { 和 } \\
33 \\
\text { 年 }\end{array}$ & \multicolumn{3}{|c|}{ 高令者70才以上 } & 64 & 53 & 8 & 2 & 22 & 5 & 2 & 43 & & \\
\hline \multirow{2}{*}{$\begin{array}{l}\text { 照 } \\
\text { 和 } \\
36 \\
\text { 年 }\end{array}$} & 高 & 令 & 者 & $\begin{array}{c}118 \\
(32.6)\end{array}$ & $\begin{array}{r}75 \\
(20.7)\end{array}$ & $\left(\begin{array}{c}26 \\
(7.2)\end{array}\right.$ & $\begin{array}{c}12 \\
(3.2)\end{array}$ & $\begin{array}{c}54 \\
(14.9)\end{array}$ & $\begin{array}{c}14 \\
(3.8)\end{array}$ & $\begin{array}{c}12 \\
(3.3)\end{array}$ & $\left(\begin{array}{c}4 \\
(1)\end{array}\right.$ & $\begin{array}{c}66 \\
(18.2)\end{array}$ & 361 \\
\hline & 若 & & 者 & $\begin{array}{c}65 \\
(10.9)\end{array}$ & $\begin{array}{c}27 \\
(4.5)\end{array}$ & $\begin{array}{c}3 \\
(0.5)\end{array}$ & $\begin{array}{c}8 \\
(1.3)\end{array}$ & $\begin{array}{c}30 \\
(5.2)\end{array}$ & $\left(\begin{array}{c}12 \\
2.0\end{array}\right.$ & $\left(\begin{array}{c}2 \\
0.3\end{array}\right)$ & $\begin{array}{c}51 \\
(8.6)\end{array}$ & $\begin{array}{c}395 \\
(66.8)\end{array}$ & 591 \\
\hline \multirow{2}{*}{$\begin{array}{l}\text { 照 } \\
\text { 和 } \\
40 \\
\text { 年 }\end{array}$} & 高 & & & $\begin{array}{c}148 \\
(19.5)\end{array}$ & $\begin{array}{c}104 \\
(13.7)\end{array}$ & $\begin{array}{c}19 \\
(2.5)\end{array}$ & $\begin{array}{c}16 \\
(1.9)\end{array}$ & $\begin{array}{c}41 \\
(5.4)\end{array}$ & $\begin{array}{c}20 \\
(2.6)\end{array}$ & $\begin{array}{c}23 \\
(3.0)\end{array}$ & $\begin{array}{c}9 \\
(1.1)\end{array}$ & $\begin{array}{c}416 \\
(55.0)\end{array}$ & 756 \\
\hline & 若 & 年 & 者 & $\begin{array}{c}89 \\
(12.1)\end{array}$ & $\begin{array}{c}33 \\
(4.5)\end{array}$ & $\left(\begin{array}{c}6 \\
0.8\end{array}\right)$ & $\left(\begin{array}{c}11 \\
1.5)\end{array}\right.$ & $\begin{array}{c}51 \\
(6.9)\end{array}$ & $\left(\begin{array}{c}7 \\
0.9\end{array}\right)$ & $\left(\begin{array}{c}2 \\
0.4\end{array}\right)$ & $\begin{array}{c}49 \\
(6.6)\end{array}$ & $\begin{array}{c}485 \\
(66.1)\end{array}$ & 733 \\
\hline \multirow{2}{*}{$\begin{array}{l}\text { 照 } \\
\text { 和 } \\
45 \\
\text { 年 }\end{array}$} & 高 & & & $\begin{array}{c}406 \\
(17.3)\end{array}$ & $\begin{array}{c}306 \\
(13.0)\end{array}$ & $\left(\begin{array}{c}71 \\
3.0\end{array}\right)$ & $\begin{array}{c}36 \\
(1.5)\end{array}$ & $\begin{array}{c}85 \\
(3.6)\end{array}$ & $\begin{array}{c}80 \\
(3.4)\end{array}$ & $\begin{array}{c}64 \\
(2.7)\end{array}$ & $\left(\begin{array}{c}32 \\
(1.3)\end{array}\right.$ & $\begin{array}{c}1263 \\
(53.9)\end{array}$ & 2343 \\
\hline & 若 & 年 & 者 & $\begin{array}{l}209 \\
(3.8)\end{array}$ & $\begin{array}{c}82 \\
(1.5)\end{array}$ & $\left(\begin{array}{c}14 \\
0.2)\end{array}\right.$ & $\begin{array}{c}28 \\
(0.5)\end{array}$ & $\begin{array}{c}65 \\
(1.2)\end{array}$ & $\left(\begin{array}{c}21 \\
0.3)\end{array}\right.$ & $\left(\begin{array}{l}0 \\
0\end{array}\right)$ & $\begin{array}{c}43 \\
(0.7)\end{array}$ & $\begin{array}{c}4943 \\
(91.4)\end{array}$ & 5405 \\
\hline \multirow{2}{*}{$\begin{array}{l}\text { 昭 } \\
\text { 和 } \\
50 \\
\text { 年 }\end{array}$} & 高 & & & $\begin{array}{c}466 \\
(23.3)\end{array}$ & $\begin{array}{c}427 \\
(21.3)\end{array}$ & $\begin{array}{l}109 \\
(5.4)\end{array}$ & $\left(\begin{array}{c}53 \\
2.6)\end{array}\right.$ & $\begin{array}{c}260 \\
(13.0)\end{array}$ & $\begin{array}{l}116 \\
(5.8)\end{array}$ & $\begin{array}{l}103 \\
(5.1)\end{array}$ & $\begin{array}{c}39 \\
(1.9)\end{array}$ & $\begin{array}{c}424 \\
(21.2)\end{array}$ & 1997 \\
\hline & 若 & 年 & 者 & $\begin{array}{c}92 \\
(2.9)\end{array}$ & $\begin{array}{c}44 \\
(1.4)\end{array}$ & $\begin{array}{c}3 \\
(0.09)\end{array}$ & $\begin{array}{c}22 \\
(0.7)\end{array}$ & $\begin{array}{c}49 \\
(1.5)\end{array}$ & $\begin{array}{c}14 \\
(0.4)\end{array}$ & $\begin{array}{c}7 \\
(0.2)\end{array}$ & $\begin{array}{c}39 \\
(1.2)\end{array}$ & $\begin{array}{c}2850 \\
(91.3)\end{array}$ & 3120 \\
\hline
\end{tabular}

数字は実数，（）内は\%を表す。

第 2 表 日本病理剖検輯報悪性新生物統計（우

\begin{tabular}{|c|c|c|c|c|c|c|c|c|c|c|c|c|}
\hline & & 胃 & 肺 & 食 道 & 腸 & 胆 - 肝臓 & 膵 & 子 宮 & 乳 房 & 細網肉腫 & その他 & 総 \\
\hline $\begin{array}{l}\text { 昭 } \\
\text { 和 }\end{array}$ & $\begin{array}{l}\text { 高令 者 } \\
70 \text { 才以上 }\end{array}$ & 23 & 10 & 3 & 2 & 15 & 7 & 3 & 4 & 5 & & \\
\hline $\begin{array}{l}33 \\
\text { 年 }\end{array}$ & $\begin{array}{l}\text { 若年者 } \\
40 \text { 才以等 }\end{array}$ & 74 & 11 & 1 & 3 & 11 & 6 & 51 & 18 & 21 & & \\
\hline $\begin{array}{l}\text { 昭 } \\
\text { 和 }\end{array}$ & 高 令 者 & $\begin{array}{r}52 \\
(22.9)\end{array}$ & $\begin{array}{c}23 \\
(10.1)\end{array}$ & $\left(\begin{array}{c}7 \\
(3.0)\end{array}\right.$ & $\begin{array}{c}10 \\
(4.4)\end{array}$ & $\begin{array}{c}47 \\
(20.7)\end{array}$ & $\left(\begin{array}{c}11 \\
4.8)\end{array}\right.$ & $\begin{array}{c}12 \\
(5.2)\end{array}$ & $\left(\begin{array}{c}4 \\
1.7\end{array}\right)$ & $\begin{array}{c}7 \\
(3.0)\end{array}$ & $\begin{array}{c}54 \\
(23.7)\end{array}$ & 227 \\
\hline $\begin{array}{l}36 \\
\text { 年 }\end{array}$ & 若 年 者 & $\begin{array}{c}78 \\
(15.7)\end{array}$ & $\left(\begin{array}{c}15 \\
3.0\end{array}\right)$ & $\left(\begin{array}{c}2 \\
0.4\end{array}\right)$ & $\left(\begin{array}{c}6 \\
(1.2)\end{array}\right.$ & $\begin{array}{c}17 \\
(3.4)\end{array}$ & $\left(\begin{array}{c}3 \\
0.6\end{array}\right)$ & $\begin{array}{c}67 \\
(13.5)\end{array}$ & $\left(\begin{array}{c}24 \\
4.8)\end{array}\right.$ & $\begin{array}{c}31 \\
(6.2)\end{array}$ & $\begin{array}{c}251 \\
(50.8)\end{array}$ & 494 \\
\hline $\begin{array}{l}\text { 照 } \\
\text { 和 }\end{array}$ & 高 令 者 & $\begin{array}{c}31 \\
(9.8)\end{array}$ & $\begin{array}{c}36 \\
(11.4)\end{array}$ & $\begin{array}{c}8 \\
(2.5)\end{array}$ & $\begin{array}{c}5 \\
(1.5)\end{array}$ & $\begin{array}{c}15 \\
(4.7)\end{array}$ & $\begin{array}{c}5 \\
(1.9)\end{array}$ & $\begin{array}{r}5 \\
(1.5)\end{array}$ & & $\begin{array}{c}7 \\
(2.2)\end{array}$ & $\begin{array}{c}202 \\
(64.3)\end{array}$ & 314 \\
\hline $\begin{array}{l}40 \\
\text { 年 }\end{array}$ & 若 年 者 & $\begin{array}{c}80 \\
(16.8)\end{array}$ & $\left(\begin{array}{c}13 \\
2.7)\end{array}\right.$ & $\left(\begin{array}{c}3 \\
0.6\end{array}\right)$ & $\left(\begin{array}{c}10 \\
2.1)\end{array}\right.$ & $\left(\begin{array}{c}34 \\
7.1\end{array}\right)$ & $\left(\begin{array}{c}11 \\
2.3)\end{array}\right.$ & $\left(\begin{array}{c}23 \\
4.8)\end{array}\right.$ & & $\begin{array}{c}14 \\
(2.9)\end{array}$ & $\begin{array}{c}287 \\
(60.4)\end{array}$ & 475 \\
\hline $\begin{array}{l}\text { 昭 } \\
\text { 和 }\end{array}$ & 高 令 者 & $\left(\begin{array}{l}112 \\
7.5)\end{array}\right.$ & $\begin{array}{c}95 \\
(6.4)\end{array}$ & $\begin{array}{c}13 \\
(0.8)\end{array}$ & $\begin{array}{c}37 \\
(2.5)\end{array}$ & $\begin{array}{c}68 \\
(4.5)\end{array}$ & $\begin{array}{c}42 \\
(2.8)\end{array}$ & $\begin{array}{c}52 \\
(3.5)\end{array}$ & $\left(\begin{array}{c}22 \\
1.4\end{array}\right)$ & $\begin{array}{c}14 \\
(0.9)\end{array}$ & $\begin{array}{l}1024 \\
(69.2)\end{array}$ & 1479 \\
\hline $\begin{array}{l}45 \\
\text { 年 }\end{array}$ & 若 年 者 & $\begin{array}{l}229 \\
(5.9)\end{array}$ & $\begin{array}{c}37 \\
(0.9)\end{array}$ & $\left(\begin{array}{c}4 \\
0.1\end{array}\right)$ & $\left(\begin{array}{c}23 \\
0.6\end{array}\right)$ & $\left(\begin{array}{c}22 \\
0.5)\end{array}\right.$ & $\left(\begin{array}{c}15 \\
0.3)\end{array}\right.$ & $\begin{array}{c}38 \\
(0.9)\end{array}$ & $\left(\begin{array}{c}37 \\
0.9)\end{array}\right.$ & $\left(\begin{array}{c}14 \\
0.3)\end{array}\right.$ & $\begin{array}{c}3398 \\
(89.0)\end{array}$ & 3817 \\
\hline $\begin{array}{l}\text { 昭 } \\
\text { 和 }\end{array}$ & 高 令 者 & $\begin{array}{c}215 \\
(21.1)\end{array}$ & $\begin{array}{c}139 \\
(13.0)\end{array}$ & $\left(\begin{array}{c}34 \\
3.1)\end{array}\right.$ & $\left(\begin{array}{c}25 \\
2.3)\end{array}\right.$ & $\begin{array}{c}176 \\
(16.5)\end{array}$ & $\begin{array}{c}72 \\
(6.7)\end{array}$ & $\begin{array}{c}59 \\
(5.5)\end{array}$ & $\left(\begin{array}{c}35 \\
3.2\end{array}\right)$ & $\left(\begin{array}{c}20 \\
(1.8)\end{array}\right.$ & $\begin{array}{c}290 \\
(27.2)\end{array}$ & 1065 \\
\hline $\begin{array}{l}50 \\
\text { 年 }\end{array}$ & 若 年 者 & $\begin{array}{c}96 \\
(13.4)\end{array}$ & $\begin{array}{c}25 \\
(3.5)\end{array}$ & $\left(\begin{array}{c}2 \\
0.2\end{array}\right)$ & $\left(\begin{array}{c}11 \\
1.5\end{array}\right)$ & $\left(\begin{array}{c}16 \\
2.2)\end{array}\right.$ & $\left(\begin{array}{c}7 \\
0.9\end{array}\right)$ & $\begin{array}{c}38 \\
(5.3)\end{array}$ & $\begin{array}{c}36 \\
(5.0)\end{array}$ & $\begin{array}{c}17 \\
(2.3)\end{array}$ & $\begin{array}{c}470 \\
(65.9)\end{array}$ & 713 \\
\hline
\end{tabular}

数字は実数，（）は\%を表す。 
第 3 表 覀性腫瘍統計（令）（厚生大臣官房統計調查部）

\begin{tabular}{|c|c|c|c|c|c|c|c|c|c|c|c|}
\hline & & & & 胃 & 気管・肺 & 肝 - 胆囊 & 直 · 大腸 & 食 道 & 脺 臓 & その他 & 総 数 \\
\hline \multirow{2}{*}{$\begin{array}{l}\text { 昭 } \\
\text { 和 } \\
33 \\
\text { 年. }\end{array}$} & \multicolumn{3}{|c|}{ 高令者 70 才以上 } & $\begin{array}{c}7604 \\
(53.0)\end{array}$ & $\begin{array}{l}957 \\
(6.7)\end{array}$ & $\begin{array}{c}1662 \\
(11.6)\end{array}$ & $\begin{array}{c}951 \\
(6.6)\end{array}$ & $\begin{array}{l}905 \\
(6.3)\end{array}$ & $\left(\begin{array}{l}175 \\
1.2)\end{array}\right.$ & $\begin{array}{c}2091 \\
(14.6)\end{array}$ & 14345 \\
\hline & \multicolumn{3}{|c|}{ 若年者40才以下 } & $\begin{array}{c}837 \\
(26.2)\end{array}$ & $\left(\begin{array}{c}84 \\
2.6)\end{array}\right.$ & $\begin{array}{l}156 \\
4.9)\end{array}$ & $\begin{array}{l}158 \\
5.0\end{array}$ & $\left(\begin{array}{c}21 \\
0.7\end{array}\right)$ & $\begin{array}{c}32 \\
(1.0)\end{array}$ & $\begin{array}{c}1899 \\
(60.0)\end{array}$ & 3187 \\
\hline \multirow{2}{*}{$\begin{array}{l}\text { 昭 } \\
\text { 和 } \\
36 \\
\text { 年 }\end{array}$} & 高 & 令 & & $\begin{array}{c}8766 \\
(51.0)\end{array}$ & $\begin{array}{c}1297 \\
(7.5)\end{array}$ & $\begin{array}{c}1919 \\
(11.2)\end{array}$ & $\begin{array}{c}1137 \\
(6.6)\end{array}$ & $\begin{array}{c}1094 \\
(6.4)\end{array}$ & $\left(\begin{array}{l}274 \\
1.6)\end{array}\right.$ & $\begin{array}{c}2714 \\
(15.8)\end{array}$ & 17201 \\
\hline & 若 & 年 & 者 & $\begin{array}{c}935 \\
(26.0)\end{array}$ & $\left(\begin{array}{l}116 \\
3.2\end{array}\right)$ & $\begin{array}{l}215 \\
(6.0)\end{array}$ & $\left(\begin{array}{l}172 \\
4.8)\end{array}\right.$ & $\left(\begin{array}{c}24 \\
0.7)\end{array}\right.$ & $\begin{array}{c}58 \\
(1.6)\end{array}$ & $\begin{array}{c}2080 \\
(57.8)\end{array}$ & 3600 \\
\hline \multirow{2}{*}{$\begin{array}{l}\text { 昭 } \\
\text { 和 } \\
40 \\
\text { 年 }\end{array}$} & 高 & 令 & 者 & $\begin{array}{l}10096 \\
(48.6)\end{array}$ & $\begin{array}{c}1959 \\
(9.4)\end{array}$ & $\begin{array}{c}2192 \\
(10.6)\end{array}$ & $\left(\begin{array}{c}1421 \\
6.8)\end{array}\right)$ & $\left.\begin{array}{c}1253 \\
6.0\end{array}\right)$ & $\left(\begin{array}{l}473 \\
2.3)\end{array}\right.$ & $\begin{array}{c}3360 \\
(16.2)\end{array}$ & 20754 \\
\hline & 若 & 年 & 者 & $\begin{array}{c}1213 \\
(28.2)\end{array}$ & $\begin{array}{l}147 \\
3.4)\end{array}$ & $\begin{array}{l}222 \\
5.2)\end{array}$ & $\left(\begin{array}{l}268 \\
6.2)\end{array}\right.$ & $\left(\begin{array}{c}21 \\
0.5)\end{array}\right.$ & $\begin{array}{c}73 \\
(1.7)\end{array}$ & $\begin{array}{c}2355 \\
(54.8)\end{array}$ & 4299 \\
\hline \multirow{2}{*}{$\begin{array}{l}\text { 昭 } \\
\text { 和 } \\
45 \\
\text { 年 }\end{array}$} & 高 & 令 & 者 & $\begin{array}{l}12295 \\
(45.3)\end{array}$ & $\begin{array}{c}3105 \\
(11.4)\end{array}$ & $\begin{array}{c}2851 \\
(10.5)\end{array}$ & $\begin{array}{c}1966 \\
(7.2)\end{array}$ & $\left(\begin{array}{c}1805 \\
6.7)\end{array}\right.$ & $\begin{array}{c}813 \\
(3.0)\end{array}$ & $\begin{array}{c}4308 \\
(15.7)\end{array}$ & 27143 \\
\hline & 若 & 年 & 者 & $\begin{array}{c}1232 \\
(28.0)\end{array}$ & $\left(\begin{array}{l}135 \\
3.1\end{array}\right)$ & $\begin{array}{l}254 \\
(5.8)\end{array}$ & $\begin{array}{c}393 \\
(8.9)\end{array}$ & $\begin{array}{c}32 \\
(0.7)\end{array}$ & $\left(\begin{array}{l}106 \\
2.4\end{array}\right)$ & $\begin{array}{c}2251 \\
(51.1)\end{array}$ & 4403 \\
\hline
\end{tabular}

数字は実数，（）内は\%を表す.

第 4 表 悪性腫瘍統計（ㅇ）（厚生大臣官房統計調查部）

\begin{tabular}{|c|c|c|c|c|c|c|c|c|c|c|c|}
\hline & & & & 胃 & 気管・肺 & 直・大腸 & 子 宮 & 乳 房 & 膵 臓 & その他 & 総 数 \\
\hline \multirow{2}{*}{$\begin{array}{l}\text { 昭 } \\
\text { 和 } \\
33 \\
\text { 年 }\end{array}$} & \multicolumn{3}{|c|}{ 高令者70才以上 } & $\begin{array}{c}6064 \\
(45.1)\end{array}$ & $\begin{array}{l}392 \\
(2.9)\end{array}$ & $\begin{array}{c}1108 \\
(8.3)\end{array}$ & $\begin{array}{c}1396 \\
(10.4)\end{array}$ & $\begin{array}{l}383 \\
(2.9)\end{array}$ & $\left(\begin{array}{l}178 \\
1.3\end{array}\right)$ & $\begin{array}{c}3902 \\
(29.1)\end{array}$ & 13405 \\
\hline & \multicolumn{3}{|c|}{ 若年者 40 才以下 } & $\begin{array}{l}1191 \\
(28.7)\end{array}$ & $\begin{array}{c}78 \\
(1.9)\end{array}$ & $\left(\begin{array}{l}164 \\
4.0\end{array}\right)$ & $\begin{array}{c}612 \\
(14.8)\end{array}$ & $\begin{array}{l}215 \\
(5.2)\end{array}$ & $\begin{array}{c}46 \\
(1.1)\end{array}$ & $\begin{array}{c}1838 \\
(44.4)\end{array}$ & 4144 \\
\hline \multirow{2}{*}{$\begin{array}{l}\text { 昭 } \\
\text { 和 } \\
36 \\
\text { 年 }\end{array}$} & 高 & & 者 & $\begin{array}{c}6914 \\
(43.8)\end{array}$ & $\begin{array}{l}567 \\
(3.6)\end{array}$ & $\begin{array}{c}1451 \\
(9.2)\end{array}$ & $\begin{array}{c}1555 \\
(9.8)\end{array}$ & $\left(\begin{array}{l}440 \\
2.8)\end{array}\right.$ & $\left(\begin{array}{l}247 \\
1.6)\end{array}\right.$ & $\begin{array}{c}4616 \\
(29.2)\end{array}$ & 15790 \\
\hline & 若 & 年 & 者 & $\begin{array}{c}1225 \\
(28.4)\end{array}$ & $\left(\begin{array}{l}107 \\
2.5)\end{array}\right.$ & $\left(\begin{array}{l}181 \\
4.2\end{array}\right)$ & $\begin{array}{c}634 \\
(14.7)\end{array}$ & $\begin{array}{c}211 \\
(4.9)\end{array}$ & $\left(\begin{array}{c}42 \\
(1.0)\end{array}\right.$ & $\begin{array}{c}1918 \\
(44.4)\end{array}$ & 4318 \\
\hline \multirow{2}{*}{$\begin{array}{l}\text { 昭 } \\
\text { 和 } \\
40 \\
\text { 年 }\end{array}$} & 高 & 令 & 者 & $\begin{array}{c}7624 \\
(42.3)\end{array}$ & $\begin{array}{c}888 \\
(4.9)\end{array}$ & $\begin{array}{c}1750 \\
(9.7)\end{array}$ & $\begin{array}{c}1668 \\
(9.3)\end{array}$ & $\begin{array}{l}390 \\
(2.2)\end{array}$ & $\left(\begin{array}{l}469 \\
2.6)\end{array}\right.$ & $\begin{array}{c}5227 \\
(29.0)\end{array}$ & 18016 \\
\hline & 若 & 年 & 者 & $\begin{array}{c}1381 \\
(30.0)\end{array}$ & $\left(\begin{array}{l}125 \\
2.7\end{array}\right)$ & $\begin{array}{c}231 \\
(5.0)\end{array}$ & $\begin{array}{c}536 \\
(11.6)\end{array}$ & $\left(\begin{array}{l}225 \\
4.9)\end{array}\right.$ & $\begin{array}{c}43 \\
(0.9)\end{array}$ & $\begin{array}{c}2095 \\
(45.2)\end{array}$ & 4636 \\
\hline \multirow{2}{*}{$\begin{array}{l}\text { 昭 } \\
\text { 和 } \\
45 \\
\text { 年 }\end{array}$} & 高 & 令 & 者 & $\begin{array}{c}9030 \\
(40.5)\end{array}$ & $\begin{array}{c}1320 \\
(5.9)\end{array}$ & $\begin{array}{c}1144 \\
5.1)\end{array}$ & $\begin{array}{c}1864 \\
(8.4)\end{array}$ & $\begin{array}{l}599 \\
(2.7)\end{array}$ & $\begin{array}{l}706 \\
(3.2)\end{array}$ & $\begin{array}{c}7665 \\
(34.3)\end{array}$ & 22138 \\
\hline & 若 & 年 & 者 & $\begin{array}{c}1368 \\
(29.8)\end{array}$ & $\left(\begin{array}{l}107 \\
2.3)\end{array}\right.$ & $\begin{array}{l}297 \\
(6.5)\end{array}$ & $\left(\begin{array}{l}407 \\
(8.9)\end{array}\right.$ & $\begin{array}{l}286 \\
(6.2)\end{array}$ & $\begin{array}{c}73 \\
(1.6)\end{array}$ & $\begin{array}{c}2060 \\
(44.8)\end{array}$ & 4598 \\
\hline
\end{tabular}

数字は実数，（）内は\%を表す。

最も多い, その他の男性では肺, 大腸, 胆・肝, 食道が 多く，女性では肺・大腸・子宮・乳房が多い.

興味ある点は, 70藏以上の胃癌と肺癌を比較すると男 女共に胃癌が圧倒的に多く, 年代により 5 倍から10倍位 の開きがあるが，剖検輯報ではそれ汪どの開きが無く， せいぜい 2 倍位である. 特に, 昭和 40 年剖検輯報では,
女性で胃癌 $9.8 \%$, 肺癌 $11.4 \%$ と肺癌の方が多くなって いる点である. 又, 70歳以上の脺癌については男性で昭 和 33 年に1.2\%であったのが次第に多くなり，昭和45年 で3.0\%に上昇している. 女性でも1.3\%であったのが， $3.2 \%$ に上昇している. 剖検輯報では, 男性で昭和 36 年 $3.8 \%$ が昭和 50 年で5.8\%，女性で $4.8 \%$ $6.7 \%$ となって 
いる．しかし，厚生省死因統計の様に毎年上昇している わけでなく,その上り方も顕著でない，これは，検査が 発達した和かげで生前の膵癌の診断がかなり正確につく 様になった点や，病理解剖はすべての死亡例を解剖する わけでなく，胃癌の様に極めてありふれた例は剖検しな (場合子多々あるため胃癌の占める割合が厚生省統計 で,より多くなっているからと解釈される。

この様に剖検輯報と厚生省死因統計とは, 必ずしも一 致した成續は得られなかったが, 胃・肺・子宮・乳房, 大腸の癌が多いのは共通した所見である。

\section{胃癌について}

老年者胃癌の臨床病理学的特徵を検討するため, 国立 東一病院病理で昭和35年より昭和 45 年まで私が剖検し, 私が検査した胃癌の70歳以上の老年群 37 例, 40 歳以下の 若年群33例を比較検討した。

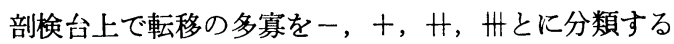
と, 老年群は州 5 例 $(13.5 \%),+1.0$ 例 $(2.7 \%),+19$ 例 $(51.3 \%),-3$ 例 $(8.1 \%)$ であるが若年群では+ 17 例 $(51.5 \%),+14$ 例 $(42.4 \%),+2$ 例 $(6.0 \%)$-は 1 例もなかった。この様に広沉な転移を示す例は若年群に 多い.

次に広汎な転移を示した州群のみにつき，どの蔵器に 転移が多いかを検討すると, 老年群 5 例, 若年群 17 例で ある. 老年群は腹膜に広汎な転移のあった例が 4 例, 主 として肝に転移のあったのが 1 例である. 若年群は17例 あり, 胸膜, 腹膜に著明な散布を示したもの11例, 肝・ 骨・肺・腎・膵に転移を多数認めたものそれぞれに 例・ 3 例・ 2 例・ 1 例・ 1 例である.中には重複してい るものもある。この様に両群共に漿膜散布が多く見られ るが, 血行性遠隔転移は若年群が多い様である.

さらに組織像を比較検討した。組織像は「外科病理胃 癌取扱い規約」により分類した。ただ再発癌も入ってい るので INF (浸潤度) は入れなかった. 又, SAT 分類 は1，2，3に各々（）をつ仔て表した。組織標本の 十分に残存している例の及選んだので老年群29例, 若年 群25例を対象とした. CAT (細胞異型度) については老 年群で CAT I 3\%, II 51\%, II 45\%であるが, 若年群 では CAT I 0\%， II 20\%，III 80\%である. SAT (組 織異型度）に関しては老年群で SAT (1) $10 \% ，(2)$ $58 \% ，(3) 32 \%$ ，若年群では SAT (1) $0 \%$ ，(2) $20 \%$ ，（3） $80 \%$ である．この様に老年者胃癌の組織像 は, 若年胃癌に比して細胞異型度, 組織異型度が低い。
老年群に全身転移の少ない理由の一つと考光られる。

\section{肺癌について}

70歳以上の肺癌に関し，小六氏，森田氏，田内教授ら は, 病理組織学的に扁平上皮癌の最も多いことを指摘し た。

私も昭和34年より 47 年の間に自分で剖検した肺癌のう ち，70歳以上 32 例，40歳以下 9 例を比較検討した. 剖検 台上での転移の多寒を胃癌剖検例と同じクライテリヤで 分けると, 70 歳以上肺癌で -3 例, + 4 例, +120 例, $H$ 5 例, 40 歳以下肺癌では+ 7 例, 卅 2 例で一, 十は共に 認められなかった。

組織学的に老年群は扁平上皮癌17例, 腺癌10例, 未分 化癌 5 例であり, 若年群では扁平上皮癌 2 例, 腺癌 3 例, 未分化癌 4 例である. 雨群を比較すると其れ其れの 群の総数が異なるので確実なことは言えないが，やはり 老年群に扁平上皮癌が多いと言える。

\section{前立腺癌について}

前立腺癌は特殊な癌で, 血中酸ホスファターゼが多く なったり，女性ホルモンで発育が抑制されたりする。し かし, 癌の中でも比較的高年齡群に多発する事実や，第 1 回老年医学会会長を務められた恩師緒方知三郎先生が 椎患された点などから検討してみた。

昭和 40 年より昭和 48 年まで国立東一病院及びメディカ ルサイェンスで私が診断した前立腺癌は40例あるが，そ の内 50 歳以下 6 例, 80 歳以上 5 例（大抵の癌は70歳以上 と40歳以下を比較したが, 前立腺癌は比較的高龄者が多 いのでこの様な方法をとった）を比較した。組織学的ク ライテリヤは胃癌と同じである.50歳以下では CAT I $16.6 \%$, II $50 \%$, III $33.3 \%$, SAT (1) $33.3 \%$, (2) $0 \%, \quad(3) \quad 66.6 \%, 1 \mathrm{NF} \alpha \quad 0 \%, \beta 40 \%, \gamma 60 \%$ であ る. 80歳以上では C.AT I $0 \%$, II $80 \%$, III $20 \%$, SAT (1) $0 \%$, (2) $20 \%$, (3) $80 \%, \operatorname{INF} \alpha 0$ $\%, \beta 20 \%, \gamma 80 \%$ で若年群も老年群もとれ程著明な差 はない。

\section{大腸直腸癌について}

老年者癌の中で比較的頻度の高い大腸直晹及び乳癌を 病理組織学的に検討した。材料はすべて昭和 41 年より約 10年間日本医大第一病院外科で手術したものである.こ の研究に協力して載いた土屋喜哉講師初め医局員の方々 に感謝する。 
大腸直腸癌は 70 歳以上 22 例, 40 歳以下 18 例を比較し た.

老年群では CAT I $4.5 \%$ ， II $77.2 \%$, III $18.1 \%$, SAT (1) $13.6 \%$, (2) $86.3 \%$, (3) $0 \%, \quad \mathrm{INF} \alpha$ $9 \%, \beta 90.9 \%, \quad \gamma 0 \%$ ある. 若年群では CAT I $0 \%$, II $55.5 \%$, III $44.4 \%$, SAT (1) $5.5 \%$, (2) $55.5 \%$, , (3) $38.8 \%$, INF $\alpha \quad 0 \%, \beta 88.8 \%, \gamma 11.1$ \%,である。老年群は若年群に比し細胞異型度組織異型 度が少なく，浸潤度も弱い傾向にあることが推定され る.

\section{乳癌について}

乳癌に関しては, 70 歳以上 7 例, 40 歳以下 6 例で症例 数は少ない. 大部分はこの間に集中するものと考兄られ る.

老年群では CAT I $14.3 \%$ ， II $57.1 \%$ ， III $28.5 \%$ SAT (1) $14.3 \% ，$ (2) $57.1 \% ，$ (3) $28.5 \%$ である. 若年群では CAT I $0 \%$ ， II $50 \%$ ，III $50 \%$, SAT (1) $0 \%$ ，(2） $50 \%$ ，（3） 50\%である.

やはり老年群は若年群に比して細胞異型度, 組織異型 度が低い傾向にある。

\section{重複密について}

剖検輯報で統計を調べていると70歳以上の老年者剖検 例に重複癌の多いのが目立つ.40歳以下の若年者剖検重 複癌と比較すると, 70 歳以上男性では昭和 43 年重複癌総 数 137 例中 54 例 $(39.4 \%) ， 45$ 年総数 145 例中 62 例 $(42.7$ $\%), 48$ 年総数 269 例中 108 例 $(40.1 \%), 50$ 年総数 283 例 中117例 $(41.3 \%)$ である. 40 歳以下では昭和 43 年 4 例 $(2.9 \%), 45$ 年 5 例 $(3.4 \%), 48$ 年10例 $(3.7 \%), 50$ 年 7 例 $(2.4 \%)$ である.女性の場合も約同様で，70歳以 上では，昭和 43 年重複癌総数 84 例中 17 例 $(20.2 \%), 45$ 年100例中 31 例 $(31.0 \%), 48$ 年153年中 55 例 $(35.9 \%)$, 50 年143例中 44 例 $(30.7 \%)$ に 比し 40 歳以下では昭和 43 年 7 例 $(8.3 \%), 45$ 年 8 例 $(8 \%), 48$ 年 8 例 $(5.2 \%)$, 50 年 6 例 $(4.1 \%)$ である.

老年になれば一つの臓器のみならず, 複数の臓器に癌 が発生し易くなる。

当研究所は老化に関する研究を行なっており, ウイス ター系ラットも加龄之共に腫崲発生が多くなる.杉山誠 講師によれば, 雌のみの成績で, 生存期間16力月, 20 力 月，24カ月でそれぞれ 隀痬発生率は $35.7 \% ， 63.2 \%$, $80.0 \%$ と上昇する。
私の剖検した重複癌で最も印象的なのは, 昭和 46 年 8 月に国立東一病理で 剖検した著明な政治家松村謙三氏 （88歳）である．氏は昭和27年頃より胆石症の発作があ り，石の排出が証明されたこともあったと言う．高血圧 症及び冠不全で入院中であった. 加えて黄疸があり, 胆 石症の診断ひついていた.

剖検すると，(1) 十二指腸乳頭部腺癌，(2) 盲腸部腺 癌, (3) 膀胱の移行上皮癌があった。転移は肝に僅かに 認められたのみで，直接死因は肺炎であった。臨床的に 癌の診断の出来なかったのは，転移がほとんど無かった のが最も大きい原因と考学られる。

老年者の胃癌, 肺癌, 乳癌, 大腸直腸癌及び肉腫を病 理学的に検索して最も目立つのは, 若年群は老年群に比 較し, 剖検台上に於ける転移巣が広汎且.つ多数である点 と組織学的分化度が低い点である.この 2 つは決して相 反するものでなく, 寧ろ, 組織学的分化度が低いから転 移が早く多いと言える。

しかし，転移は決して癌細胞の分化度のみに依存する ものではなく, 到達臓器の受け入れ体制や癌発育の時間 的余裕も考慮されねばならない。

胃癌はすべて剖検例を検討したが，70歳以上老年群は 胃癌発生より死亡までの期間が若年群に比して短いので はないか, そのために各蔵器に転移する時間がなく, 剖 検時には一見転移が少ない様に見光るのではないか。こ んな疑いから非手術例胃癌の中から 40 歳以下 18 例, 70 歳 以上20例を選んで胃癌が出来てから死亡するまでの期間 を推定した.手術例は手術による影響を考慮して除いた。

これは極めて困難且つ客観的説得力の乏しい仕事だ が, 受持ちの臨床医と 1 例, 1 例生前の症状, データを 参考に計算した. 癌としての症状が出てから死亡するま での期間を 3 カ月まで，4 カ月より 7 カ月まで， 8 カ月 より11カ月まで，12カ月より14カ月まで，15力月より 18 カ月まで，18カ月以上の 6 つに分けると若年群はそれぞ れ 4 例, 6 例, 2 例, 1 例, 4 例, 1 例である. 老年群 はとれぞれ 7 例, 6 例， 3 例， 2 例， 2 例で18力月以上 生存した例はない。この数值を正しいものとすれば, 2 群共に大部分 12 力月以内で死亡する. 若年群でも 3 カ月 以内に 4 人死亡している. 又老年群でも 1 年以上生存し たのが 4 例である.このことから若年群も老年群も癌が 出来てから死亡するまでの期間にそれ程の差がないと考 えた. 結局, 今のところ, 転移の多頞の差は癌の組織像 
の差に求めるべきものと考えている.恐らく老年者癌は 分化型で, 発育のバイタリティーが若年者に比し弱いの であろら．勿論, 前述した様に各臓器の受け入れ側の体 制も考えねばならぬ.癌細胞が到達しても藏器側の事情 で発育，増殖が起らず，死隇すれば転移は全く起こらな いからである.恐らく癌細胞が，他の臟器に転移して最 初に直面するのは間質組織との攻防戦で㐫るから，その 臓器の結合織, 血管, 食細胞, リンパ球等を免度学的配 慮と共に研究するのは極めて必要なことであり，今後の 大きな課題である．故流沢教授も癌細胞と間質の関係に 注目している.ともあれ免疫学的監視が加齢と共に弱く なり癌発生の一因となり得るが，一方老年者の癌細胞は バイタリティーに欠けている。これが老年者癌の最も主 な特徴である。

老年者肺癌に扁平上皮癌の多いのは, 気管支粘膜上皮 の扁平上皮化生が影響しているのは確実だが，山田教授 の説く如く化生は必ずしも癌に直接先行するものではな い.一般に肺癌に於いて扁平上皮癌は腺癌に比し転移が 少ない，従って老年者肺癌が若年者肺癌に比し転移の少 ないのは，必ずしも年㱓の及の差でなく，その組織像の 差も考虑されねばならない。

前立腺癌は老年者と若年者の間に差を認めなかった が，数を増して再娭討したい。

\section{結 論}

70 歳以上の高年.跉者悪性腫瘍の所見及び特徵は次の如 きである。

1. 肉腫のうち最も多いのは細網肉腫である。骨肉 腫, 線維肉腫で組織学的にかなり分化しているものもあ る。

2. 剖検, 生検ともに最も多いのは胃癌である. 次い で肺, 子宮, 乳房, 大腸・直腸, 食道, 胆・肝癌が高頻 度に認められる。

3. 厚生省大臣官房統計調査部死因統計を検討する と, 膵癌死亡率が男女ともに上昇し, 昭和45年では昭和 33年のほぼ 3 倍近くである。

4. 日本病理剖検輯報に上れば重複癌が多く，特に男 性では40歳以下若年群のほぼ10倍の頻度である.

5. 胃癌, 肺癌剖検例を若年群之比較すると, 老年群 は転移が少なく, 組織学的に細胞異型度, 組織異型度が 少なく, 分化型が多い。肺癌は扁平上皮癌が多い。

6. 大腸直腸癌, 乳癌の組織像子若年群に比し細胞異 型度, 組織異型度が少なく, 分化型が多い。浸潤度は大
腸直腸癌のみ検索したが若年群に比し軽い，

7. 前立腺㗊は例数の関係で80歳以上，50歳以下を比 較したが顕著な差はない，今後更に検討したい，

8. 今後の大きい課題は転移先の臓器特に 間質組織 と, 癌細胞との関係を免疫学的考虑を払いながら検索す ることである。

最後に本日の講演の機会を与えて載いた第19回日本老 年医学会会長田内久教授初め, 役員, 会員の方々に感謝 致します.

\section{文献}

1）滝沢延次郎：病理学から見た癌腫の悪性度につ いて，千葉医会誌，43 906頁 (1968).

2) 丸山雄造 : 癌と加齢, 信州医学雑誌, 21 巻 2 号 117頁 (1973).

3) 太田邦夫：老年者の腫瘍, 日内会誌, 64 巻 3 号 1 頁 (1974).

4) 田内 久:ガンと年跘, からだの科学, No. 17 . 23頁 (1967).

5）森亘：時代並びに年路的に朓めた癌の統計 学的観察, 日病会誌, 46巻 1 号 1 頁 (昭32).

6) 金子 仁：老人性悪性腫瘍の特徵, geriatric Medicine vol 12, No. 12, 12, 1 頁 (1974).

7）金子 化: 老年者の悪性腫瘍, 日本医事新報, No. 2787，46頁 (昭52).

8) 太田邦夫：老化と癌化における 2,3 の問題, 日老医誌， 9 巻 3 号, 152頁 (昭47).

9）黑川利雄, 山形敞一: 加齢と悪性腫瘍, 日老医 誌, Vol. 8 No. 2 60頁 (1971)

10) 太田邦夫他編 : 老人病, 老年学講座 1. 老年科 学振興会 (昭51).

11) 田内 久: 若年者胃癌についての病理学的考 察, 名市大医誌, 第 1 巻 1 号 5 頁（昭 $25 ）$

12）小六哲司他：高秢者肺癌67例の検討, 肺癌, 199頁 (1973).

13）森田豊彦：教室における最近17.5年問の肺癌剖 検例，癌の臨床，22巻14号，1323頁 (1076)。

14）佐藤秩子他：肺癌, 医学のあゆみ, 96 巻 5 号, 355頁 (昭51).

15）山田 明：職業性毒ガス中毒の病理解剖学的研 究, 日病会誌, 63巻 17頁 (昭49).

16) 田内 久: 肺癌進展の様相, 内科シリーズ「肺 癌のすべて」南山堂 (1974). 